Review

\title{
Advances in Ultrasound Mediated Gene Therapy Using Microbubble Contrast Agents
}

\author{
Shashank R. Sirsi ${ }^{\varpi}$, Mark A. Borden \\ Department of Mechanical Engineering, University of Colorado, Boulder, CO 80309, USA. \\ $\triangle$ Corresponding author: Shashank R. Sirsi, Department of Mechanical Engineering, University of Colorado, Boulder, CO 80309, USA. \\ (C) Ivyspring International Publisher. This is an open-access article distributed under the terms of the Creative Commons License (http://creativecommons.org/ \\ licenses/by-nc-nd/3.0/). Reproduction is permitted for personal, noncommercial use, provided that the article is in whole, unmodified, and properly cited.
}

Received: 2012.03.01; Accepted: 2012.07.01; Published: 2012.12.31

\begin{abstract}
Microbubble ultrasound contrast agents have the potential to dramatically improve gene therapy treatments by enhancing the delivery of therapeutic DNA to malignant tissue. The physical response of microbubbles in an ultrasound field can mechanically perturb blood vessel walls and cell membranes, enhancing drug permeability into malignant tissue. In this review, we discuss literature that provided evidence of specific mechanisms that enhance in vivo gene delivery utilizing microbubble contrast agents, namely their ability to I) improving cell membrane permeability, 2) modulate vascular permeability, and 3) enhance endocytotic uptake in cells. Additionally, we review novel microbubble vectors that are being developed in order to exploit these mechanisms and deliver higher gene payloads with greater target specificity. Finally, we discuss some future considerations that should be addressed in the development of next-generation microbubbles in order to improve in vivo microbubble gene delivery. Overall, microbubbles are rapidly gaining popularity as efficient gene carriers, and combined with their functionality as imaging contrast agents, they represent powerful theranostic tools for image guided gene therapy applications.
\end{abstract}

Key words: Cavitiation, Sonoporation, Targeted Image-Guided DNA Delivery.

\section{Introduction}

Microbubble ultrasound contrast agents (MCA's) are gas-filled spheres, typically between 1 and $10 \mu \mathrm{m}$ in size, stabilized by thin biocompatible shells [1]. When injected systemically, MCA's are confined to the vasculature due to their size. The compressible nature of the gas core allows MCA's to scatter ultrasound (US) energy more effectively than surrounding blood and tissue, thus making them effective probes for vascular imaging. Currently, MCA's are used clinically to monitor blood perfusion in several organs (for a recent comprehensive review on clinical applications of microbubbles, see [2]) and molecular targeting in preclinical studies [2-7] and clinical trials [8]. MCA's, although typically used to enhance US contrast for imaging, are becoming in- creasingly popular for systemically targeting drugs and genes to malignant tissue $[9,10]$.

The compressible nature of the microbubble gas core allows MCA's to volumetrically expand and contract in response to compression and rarefaction phases of ultrasound waves (stable cavitation; Fig 1A) [11]. At high pressure amplitudes, MCA's collapse violently (inertial cavitation; Figure 1B) emitting shock waves that perturb cellular membranes and disrupt vascular endothelial integrity, thus increasing permeability to circulating therapeutic agents [11]. This phenomenon, known as sonoporation, can be exploited to improve extravasation of drugs. With judicious application of ultrasound energy, the effects of sonoporation can be spatially and temporally con- 
trolled to improve localized tissue deposition of circulating nucleic acids for targeted gene therapy applications.

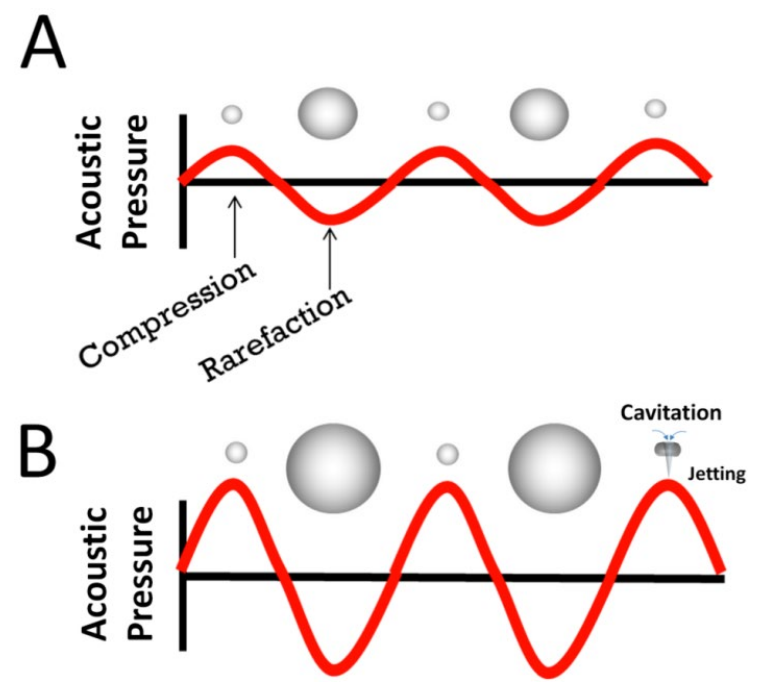

Figure I. Microbubble Response in an ultrasound field. A) Microbubbles volumetrically oscillate due to continuous changes in the external pressure caused by an acoustic sound wave. B) At high pressure amplitudes, microbubbles collapse violently, producing water jetting and shock waves, and other inertial phenomena.

Gene therapy treatment is accomplished by introduction of foreign poly(nucleic acid)'s in the form of vectors such as bacterial plasmid DNA, synthetic oligonucleotides, and viruses, to treat a wide range of debilitating genetic disorders. In this review, we focus primarily on mechanisms of DNA delivery. Currently, gene therapy treatments are limited to clinical and pre-clinical testing as commercial gene therapy products do not currently exist. The major impediments towards developing effective clinical therapies are safety concerns (especially with regard to viral vectors) [12-16] and insufficient gene expression, wherein the amount of DNA delivered is inadequate to produce a functional effect (non-viral and replication incompetent viral vectors) [16, 17]. Toxicity and inefficient gene expression can be attributed to poor circulation-profiles and undesired biolocalization of many DNA vectors. Non-viral DNA vectors are often rapidly cleared from circulation by the mononuclear phagocyte system (MPS) [18], lowering their in vivo efficacy. Viral vectors are rapidly cleared by hepatic Kuppfer cells [19], resulting in high deposition in the liver and liver-toxicity. Therefore, the use of these vectors to deliver DNA in vivo is limited by the dosage that can be administered [19]. Increasing target specificity to malignant tissue can reduce off-target bioeffects and increase the therapeutic drug index [20]. In this review, we discuss how MCA's are able to facili- tate methods of targeted DNA delivery in vivo.

For more than a decade, MCA's and US have been used in preclinical studies to augment gene expression in a site-specific manner to a variety of organs and tissue, namely the heart [21-26], pancreas [27, 28], kidney [29, 30], skeletal muscle [31-37], and tumor tissue [38-42]. However the fundamental mechanisms that increase vascular permeability in vivo are not well established. Here, we outline the proposed mechanisms involved in enhancing MCA-mediated gene transfection in vivo (Figure 2) and discuss the advances in novel MCA-based vectors that improve tissue specificity and DNA payload.

\section{Mechanisms of Microbubble Mediated DNA Delivery}

Microbubbles are typically between $1-10 \mu \mathrm{m}$ in diameter, small enough to transverse through capillary blood vessels in circulation, but too large to extravasate into extravascular tissue. Therefore, the mechanisms of MCA-mediated DNA delivery are predominately attributed to bio-effects of microbubble cavitation on the blood vessel walls and vascular endothelial cells. These bio-effects involve increasing the vascular permeability to circulating agents and facilitating their deposition in the insonified region (Figure 3). The exact mechanisms governing improved DNA transport in vivo are unclear, although there is evidence to support that microbubble cavitation alters vascular permeability by three different mechanisms: (1) creation of transient pores in vascular endothelial cells that allow intracellular macromolecule uptake, (2) disruption of vascular endothelial integrity, allowing trans-vascular macromolecule transport between cells, or (3) stimulation of endocytotic cellular uptake, promoting intracellular delivery (and possibly transcytosis). Evidence in the literature for the proposed mechanisms of DNA uptake is discussed in the following sections.

\section{Membrane Sonoporation}

Inertial cavitation of MCA's near a cell boundary can cause transient membrane ruptures due to shock waves and jetting during microbubble collapse [11]. This effect, also known as "microbubble sonoporation", has long been thought to be a major contributor towards improving intracellular drug and gene delivery $[43,44]$. The appearance of transient pores has been established in vitro through observations of intracellular nanoparticle uptake, by examining cell morphology with scanning electron microscopy (SEM), optical microscopy [45-48], and by electrophysiology techniques (e.g. patch-clamp) [49-51]. However, few studies have studied the cellular changes associated with single cavitation events. 


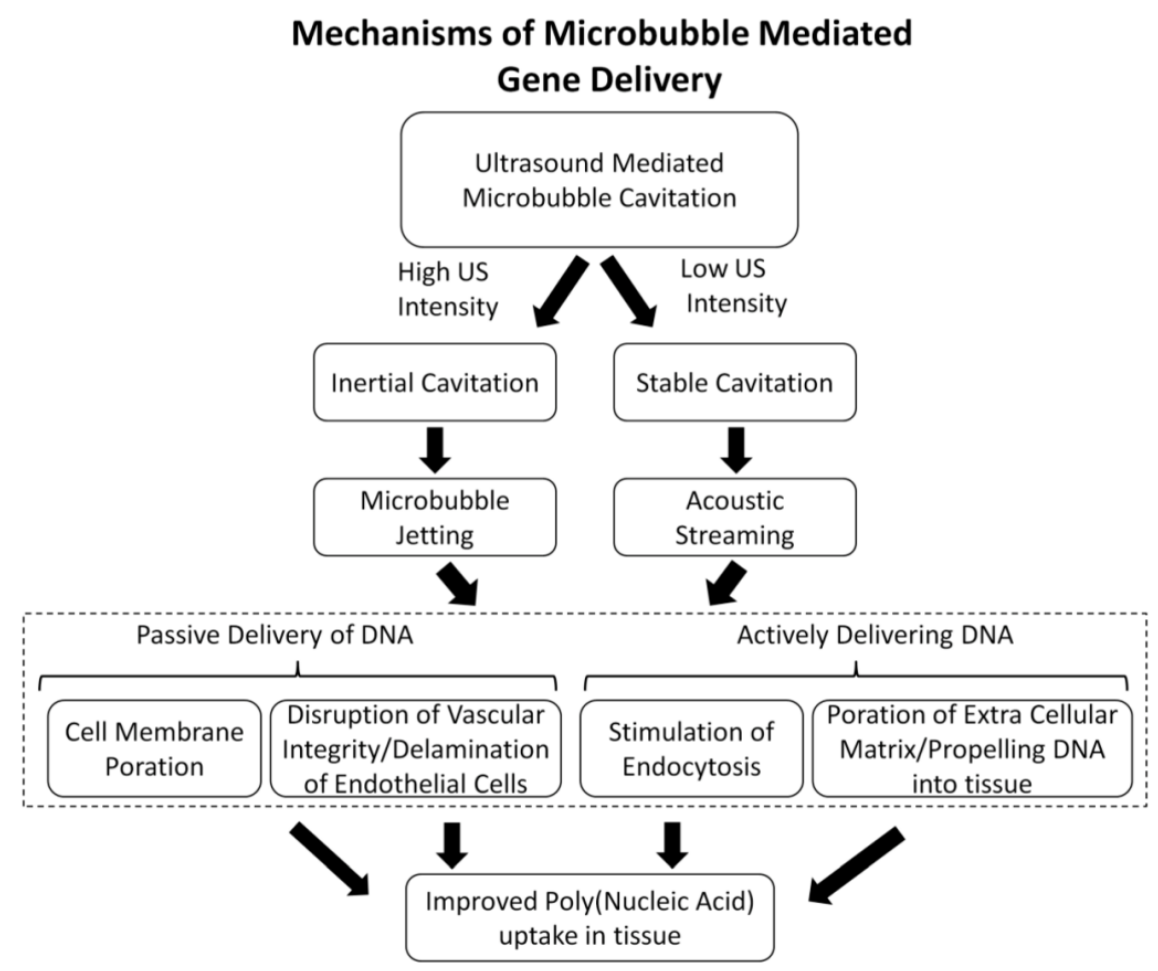

Figure 2. Flow chart outlining the potential mechanisms of improved DNA delivery in vivo. This review will focus on recent literature providing evidence towards mechanism of increasing poly (nucleic acid) delivery to cells (dashed line).

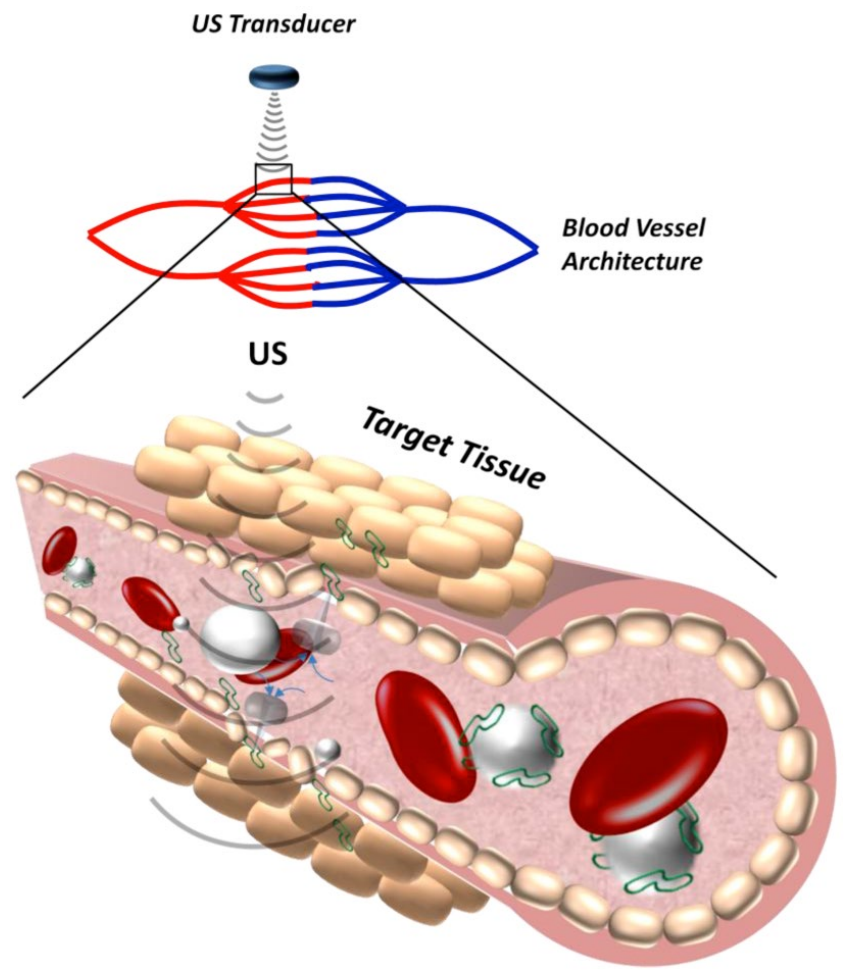

Figure 3. Schematic representation of how microbubble cavitation facilitates DNA (green) extravasation into tissue.
An elegant in vitro study was recently published by Zhou et al [52] that demonstrated the effects of single microbubbles on membrane pore formation in xenopus oocytes. In this study, an ultrasound transducer was used to push individual bubbles towards the cell membrane and subsequently create a cavitation event to induce pore formation. Single bubbles were able to generate transient pores with sizes proportional to the proximity of the cavitation event to the membrane. When microbubble cavitation occurred adjacent to the membrane, average pore sizes of $\sim 0.10-0.17 \mu \mathrm{m}$ were created using US pressure amplitudes of 1.5-1.7 MPa. Additionally, the membranes returned to normal as short as 20 seconds after sonoporation, indicating a quick re-sealing of the membrane. This novel study indicates that microbubble-mediated pore formation is a highly controllable and effective method of transiently opening membranes to facilitate intracellular gene delivery.

Recently, an alternative mechanism for cell membrane sonoporation termed the "bilayer sonophore" has been proposed [95]. This mechanism involves the nucleation and growth of a cavity between the lipid monolayer leaflets of the bilayer membranes. Such an intramembrane cavity could form at a lower acoustic pressure than that needed for inception cavitation in the aqueous phase owing to the weaker intermolecular cohesion forces between the tails of the 
the lipid acyl chains (van der Waals dispersion forces) in comparison to bulk water molecules (hydrogen bonding) [96]. Krasovitski et al. [95] used theoretical arguments to show that the presence of a nearby microbubble could amplify the local acoustic pressure and therefore enhance such intramembrane cavitation. While this is an intriguing concept, more experimental and theoretical studies are necessary to further support this as a viable mechanism for cell membrane sonoporation.
For in vivo gene therapy, sonoporation may be a highly efficient method of transfecting vascular or blood-borne cells. However, there is no evidence to suggest that membrane pore formations will adequately transfect tissue beyond the vasculature. For this to occur, DNA taken up into endothelial cells would have to be removed from the cellular space to the extrasvascular side, possibly through active exocytosis (Figure 4A). More research is necessary to determine whether membrane sonoporation can facilitate trans-vascular delivery of circulating agents.

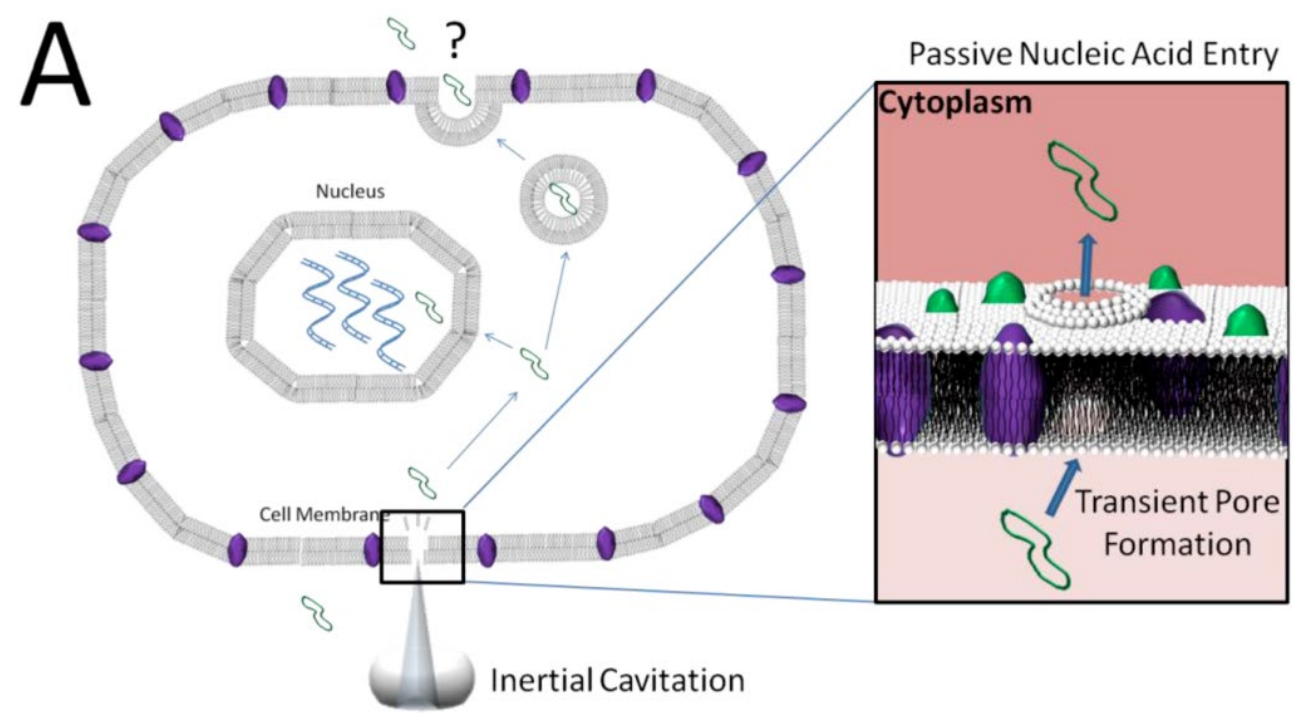

B

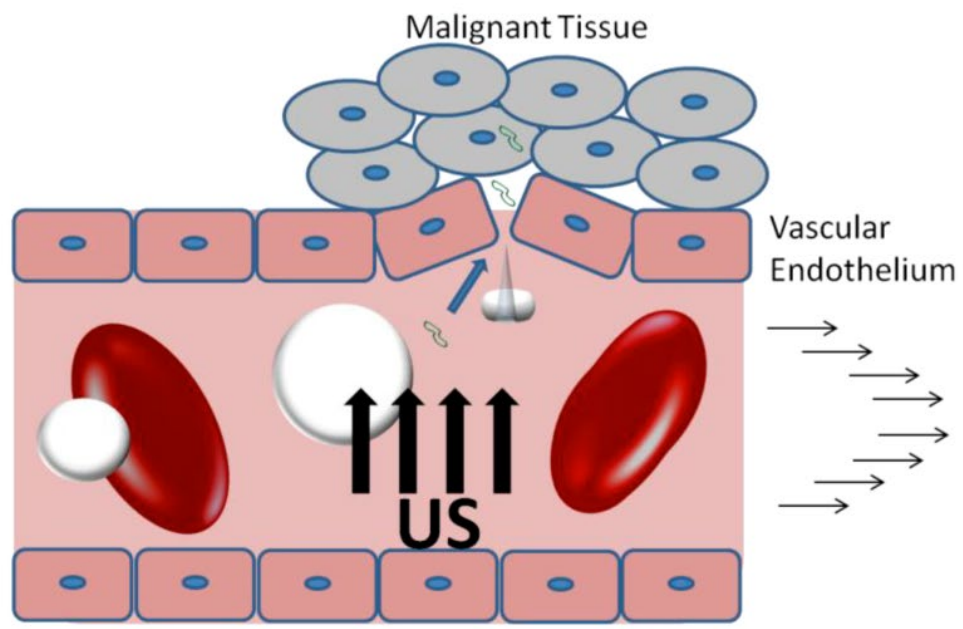

Figure 4. Mechanisms of DNA extravasation via inertial cavitation of microbubbles. A) Inertial forces from jetting during inertial cavitation transiently permeabilize cell membranes allowing direct access of circulating DNA to the cell cytoplasm. B) Inertial cavitation may disrupt vascular endothelial integrity increasing the vascular permeability to DNA in circulation. 


\section{Modulation of Vascular Integrity}

Improving gene delivery to extravascular tissue can also be accomplished by altering the vascular integrity. This mechanism, unlike sonoporation, is thought to temporarily increase the gap-junction distance between vascular endothelial cells by volumetric changes of oscillating bubbles, thus allowing circulating agents to extravasate (Figure 5). There are only a few studies which directly observe the effects of microbubble cavitation on intact blood vessels in real-time.

Caskey et al. [53] and Chen et al. [54] directly probed the interaction of microbubbles with real blood vessels during cavitation using high-speed imaging. These studies demonstrated that volumetric expansion of the microbubbles in an ultrasound field facilitated bubble-vessel interaction. In the expanded phase, the large bubbles caused a circumferential displacement of the vessels, thereby increasing dilatational strain and potentially creating large gaps be- tween cells. Interestingly, an oscillating bubble was observed to cross the endothelium while partially embedded in the vessel wall, likely caused by primary radiation forces which can push microbubbles in the direction of US propagation [55]. In a similar study, Chen et al. observed invagination of the blood vessels during the contraction phase of the bubble. The extent of vessel-wall invagination was reportedly greater than the corresponding distention, implying that increased mechanical strain on the vessel occurs from contraction rather than expansion. Since blood vessels adapt to distention from increases in blood pressure, but not to sudden radial contraction, the strain from blood vessel invagination likely leads to greater delamination of the endothelial layer (Figure 5C). Both of these studies have provided critical insights into potential mechanisms of in vivo gene transfection by demonstrating that microbubble oscillation cause mechanical strain on the blood vessel that likely alters vascular permeability.

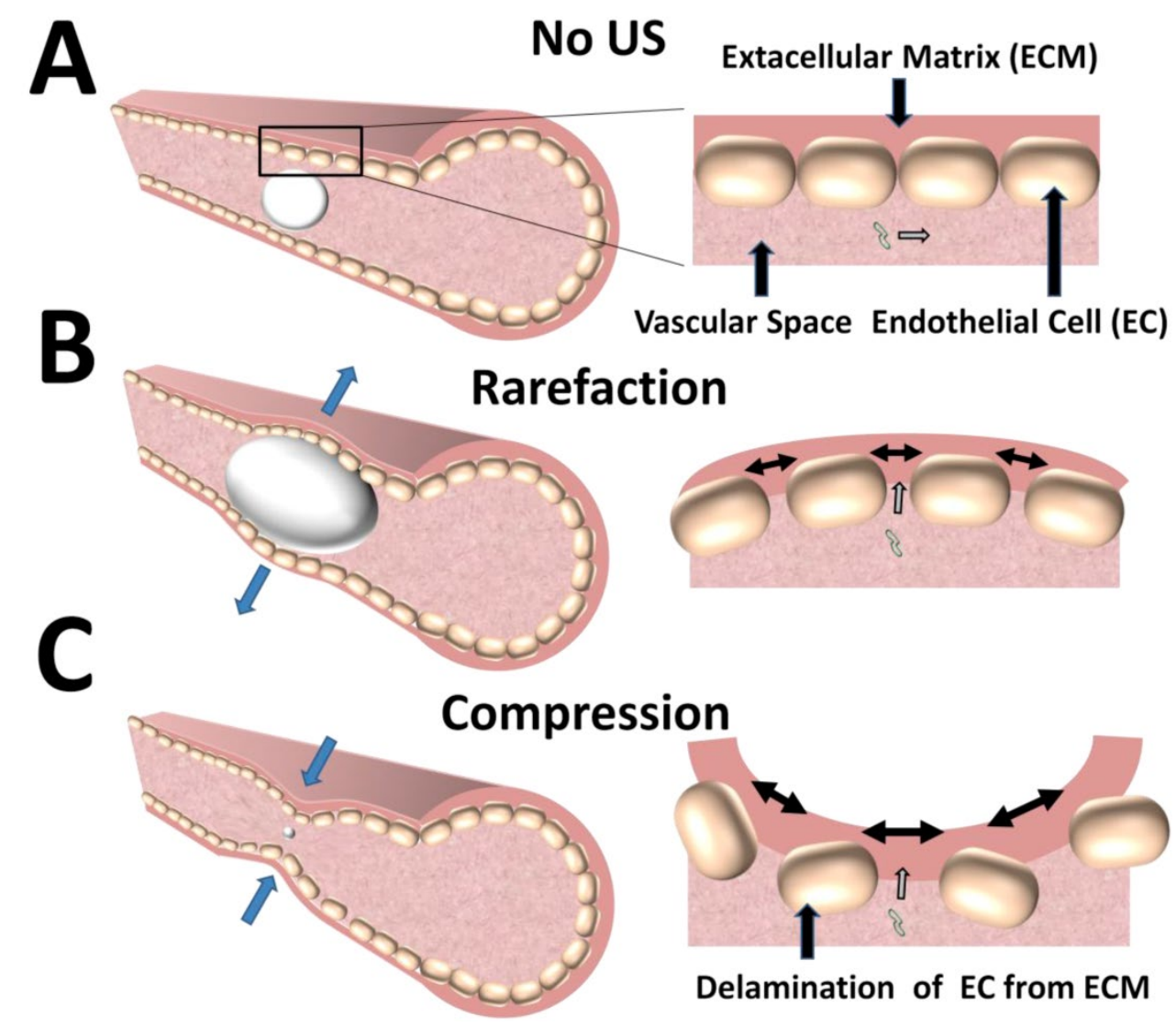

Figure 5. Mechanisms of DNA extravasation by conformational changes in blood vessels during microbubble cavitation. A) The vascular endothelium posses a significant barrier to extravasation of circulating DNA B) In an ultrasound field, microbubbles can expand to physically distend the blood vessel wall, creating intracellular gap junctions that increase permeability to circulating DNA. C) During microbubble compression, invaginations of the blood vessel wall also can cause intracellular gap junctions that allow extravasation of circulating DNA. 


\section{Stimulating Endocytotic Uptake}

The effects of microbubble cavitation on intracellular responses are often overlooked due to a prevalent notion that membrane sonoporation or mechanical disruptions of vascular integrity are primarily responsible for extravasation of circulating agents. However, recent studies are demonstrating that mechanical perturbation of the oscillating microbubbles in contact with cell membranes alter the cell membrane potentials, which subsequently affect intracellular pathways and potentially stimulate endocytotic activity (Figure 6) (see [51] for a comprehensive review). Here we discuss some of the more recent studies on the effects of MCA's on endocytotic activity.

Hauser et al. [56] and Meijering et al. [57] demonstrated that low-intensity ultrasound in cultured cells increased endocytotic activity in the pres- ence of microbubbles. Hauser et al. [56] demonstrated enhanced uptake of endocytotic markers as well as larger number of clatherin-coated pits and endocytotic vesicles in cells exposed to low-intensity ultrasound in the presence of microbubbles. Importantly, no visible damage to the cell membrane was observed. Meijering et al. [57] used fluorescently labeled dextrans of low and high molecular weights $(4 \mathrm{kDa}$ and $400 \mathrm{kDa}$ ) to transfect cultured cells in the presence of microbubbles and ultrasound. Clatherin- and caveolin- inhibitors and ATP depletion were used to inhibit endocytosis, resulting in reduced uptake of low molecular weight dextrans and no uptake of high molecular weight dextrans. The results of these studies strongly suggest that stable cavitation of microbubbles can facilitate endocytotic uptake of nucleic acids and nucleic acid vectors with minimal damage to cellular and vascular structure.

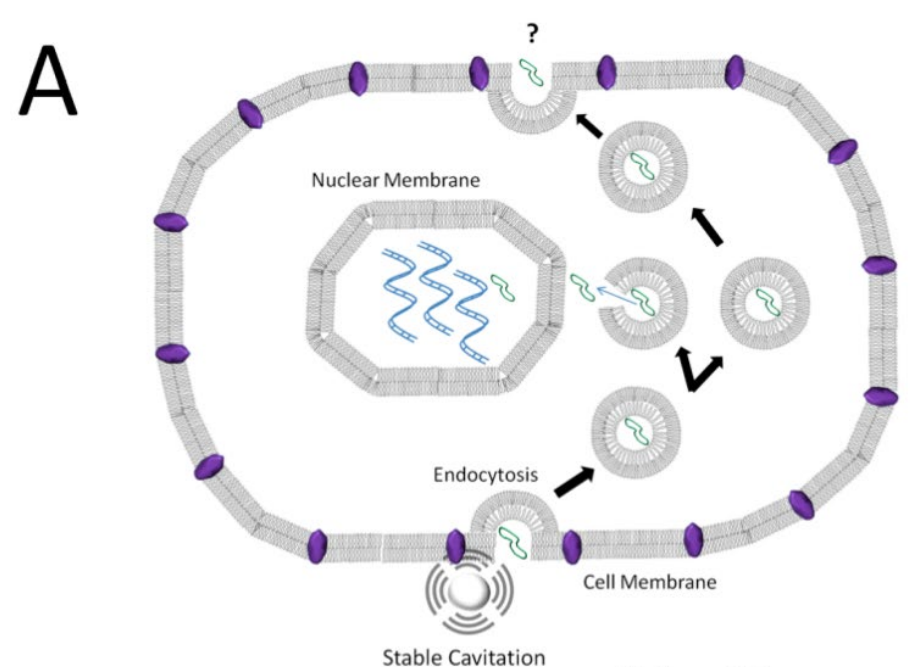

B

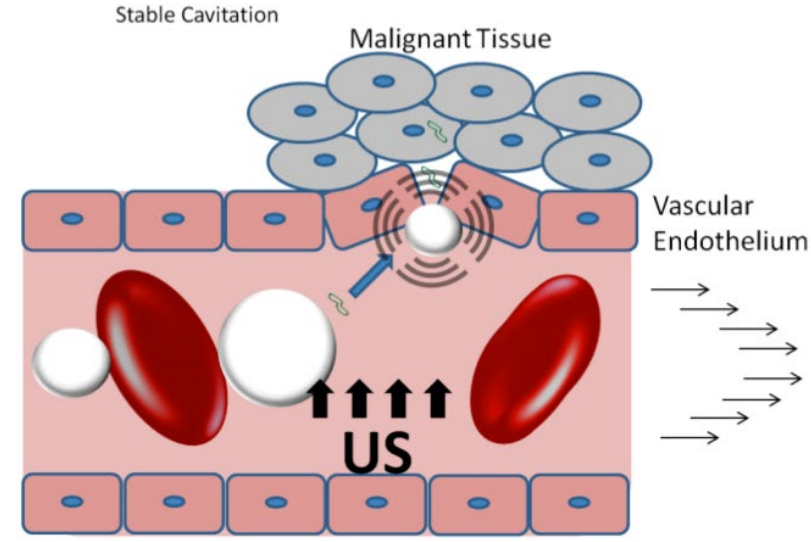

Figure 6. Mechanisms of DNA extravasation via stable cavitation of microbubbles. A) Microbubble oscillations near the cell membrane boundary stimulate endocytotic activity, promoting intracellular uptake of DNA into the cell cytoplasm. B) Stable cavitation may disrupt vascular endothelial integrity increasing the vascular permeability to DNA in circulation. 
Similar in vitro studies by Lentacker et al. and Geers et al. [58, 59] suggest that endocytosis has a more limited effect on DNA vector uptake. Lentacker et al. utilized a novel lipoplex-loaded microbubble formulation in order to determine whether lipoplex uptake, following microbubble cavitation, was caused by active endocytosis or passive cell entry [58]. The addition of an endocytotic inhibitor had no significant influence on the intracellular lipoplex uptake, indicating endocytosis is not the primary mechanism of cell entry. A follow-up study by Geers et al. [59] was performed using green fluorescent protein (GFP) expressing adeno-associated virus (AAV) vectors attached to the microbubble surface. This study demonstrated high intracellular AAV uptake but no GFP expression following US insonification. Since AAV transfection requires an active endocytotic, it was concluded that the primary mechanism of AAV entry was passive. It should be noted that the US exposure used in these experiments likely induced inertial cavitation of microbubbles, thus no conclusion can be drawn as to whether more efficient lipoplex or AAV uptake can be achieved by stable cavitation.

These novel studies have provided critical insights into the mechanisms of intracellular gene and drug uptake. However, it is still unclear whether or not endocytosis plays a significant role in US mediated gene transfection in vivo. Low-intensity ultrasound application to facilitate intracellular uptake undoubtedly has advantages, namely the lack of cellular damage and inflammation that occurs with inertial cavitation [60]. However, more research is necessary to demonstrate stable cavitation to be a viable and effective method of transducing tissue in vivo.

Table I. Summary of recent literature providing evidence for different mechanisms of gene delivery.

\begin{tabular}{|c|c|c|c|}
\hline Author & Year & Experiment & Summary \\
\hline \multicolumn{4}{|c|}{ Membrane Poration } \\
\hline Zhou et al. [52] & 2011 & $\begin{array}{l}\text { Demonstrated the effects } \\
\text { of single cavitation } \\
\text { events on individual cells }\end{array}$ & $\begin{array}{l}\text { - Membrane poration caused by inertial cavitation of } \\
\text { microbubbles } \\
\text {-- Pore size proportional to proximity of cavitating bubble to } \\
\text { cell membrane }\end{array}$ \\
\hline \multicolumn{4}{|c|}{ Disruption of Vascular Integrity } \\
\hline $\begin{array}{l}\text { Caskey et al. [53] } \\
\text { and } \\
\text { Chen et al. [54] }\end{array}$ & 2007 & $\begin{array}{l}\text { Studied Microbubble } \\
\text { interaction with real } \\
\text { blood vessels during } \\
\text { cavitation }\end{array}$ & $\begin{array}{l}\text {-Microbubble expansion causes longitudinal strain on blood } \\
\text { vessels } \\
\text {-Compressed bubbles can partially embed themselves in } \\
\text { the endothelium and continue to oscillate [54] } \\
\text { - Invagination of blood vessels during microbubble } \\
\text { contraction [55] }\end{array}$ \\
\hline \multicolumn{4}{|c|}{ Enhancing Endocytotic Uptake } \\
\hline Hauser et al. [56] & 2009 & $\begin{array}{l}\text { Studied the effects of } \\
\text { stable microbubble } \\
\text { cavitation on endocytotic } \\
\text { activity in cultured cells }\end{array}$ & $\begin{array}{l}\text { - Stable cavitation of microbubbles increases number of } \\
\text { clatherin-coated pits and endocytotic vesicles }\end{array}$ \\
\hline Meijering et al. [57] & 2009 & $\begin{array}{l}\text { Studied the effects of } \\
\text { stable cavitation on } \\
\text { endocytotic activity in } \\
\text { cultured cells }\end{array}$ & $\begin{array}{l}\text { - Inhibition of clatherin mediated process dramatically } \\
\text { reduces intracellular drug uptake } \\
\text { - Contribution of endocytosis in microbubble mediated gene } \\
\text { delivery is dependent on molecular size of drug }\end{array}$ \\
\hline \multicolumn{4}{|c|}{ Gene Delivery Beyond the Vasculature } \\
\hline $\begin{array}{l}\text { Caskey et al [61] } \\
\text { and } \\
\text { Arvantis et al. [62] }\end{array}$ & 2009 & $\begin{array}{l}\text { Studied the effects of US } \\
\text { on microbubbles in flow } \\
\text { using a tissue mimicking } \\
\text { gel phantom }\end{array}$ & $\begin{array}{l}\text {-Demonstrated that microbubbles could form tunnel s into } \\
\text { gels in the direction of US propogation } \\
\text { - Demonstrated that adenoviral vectors in flow could be } \\
\text { propelled into tumor cells seeded in gels through small } \\
\text { microchannels [62] }\end{array}$ \\
\hline
\end{tabular}




\section{Actively delivering DNA vectors - Pro- pelling beyond the vasculature}

The mechanisms of improving gene uptake that have been discussed in the preceding sections utilize MCA's as independent agents which transiently increase the vascular or cellular permeability to free-circulating agents in the blood, promoting passive uptake. In addition to modulating cell membrane and blood vessel permeability, cavitation events may facilitate extravasation of microbubbles themselves, subsequently propelling circulating agents beyond the vasculature. The idea that MCA's themselves are able to extravasate has been demonstrated in tissue-mimicking gel phantoms.

Caskey et al. [61] and Arvantis et al. [62] performed elegant in vitro studies in gel phantoms with similar Young's modulus properties to that of tissue. Lipid-shell microbubbles were insonified with varying US parameters while flowing through a hollow phantom. High-speed video imaging of the microbubble motion during US application showed that MCA's moved in the direction of US propagation, creating tunnels in the gel at high pressure amplitudes by fluid jetting. Arvantis et al. utilized a similar tissue-mimicking phantom technique to study cavitation induced extravasation of luciferase expressing adenoviral vectors (Ad-Luc) under flow conditions. BT-474 breast cancer cells were seeded in agarose gels with flow-through channels. Ad-Luc particles and MCA's were pumped through the channel while US was applied. As the US pressure increased, Ad-luc particles were able to extravasate more efficiently and transfect gel seeded cells. These novel studies suggest that circulating MCA's can extravasate and facilitate delivery beyond the confines of the vasculature.

\section{Enhancing Active DNA delivery - Drug loading onto the Microbubble Surface}

MCA mediated gene therapy studies are most commonly performed by co-injection of MCA's and DNA vectors. In these studies, circulating MCA's are insonified to increase local vascular permeability allowing DNA vectors to passively extravasate into tissue. However, circulating agents also extravasate into fenestrated organs (such as the lung, liver, and spleen), producing off-target effects. New approaches are currently being developed to physically attach DNA vectors to the MCA surface, forming MCA-DNA hybrid vectors. By attaching therapeutic agents onto the MCA surface, their release can be mediated by cavitation within the US focus, thus providing more specific control in tissue-targeting applications [63]. Furthermore, attachment of DNA to the microbubble surface has potential protective properties that may be beneficial towards preventing rapid clearance of DNA [64]. Several studies have demonstrated that molecules loaded onto microbubbles improves their intracellular uptake in vitro [65, 66] and deposition into target tissue in vivo [67]. In this section, we discuss some of the more novel advances in coupling non-viral and viral DNA vectors with MCA's for developing improved in vivo gene therapy treatments.

\section{DNA/Microbubble Hybrid Vectors for in vivo DNA Delivery}

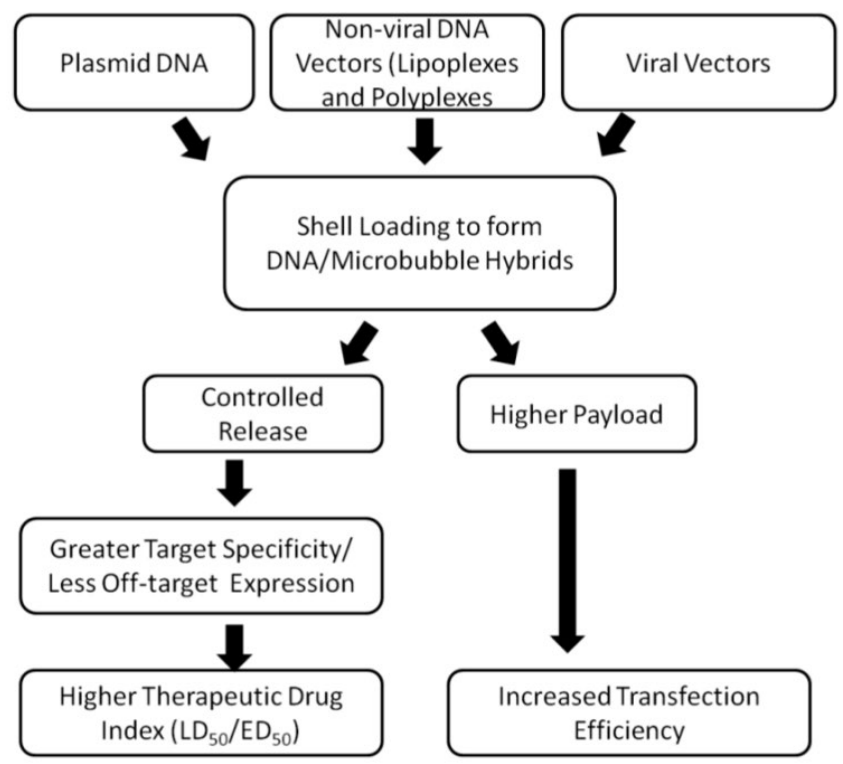

Figure 7. Flowchart describing the advantages of DNA/Microbubble hybrid vectors.

\section{Microbubble/Plasmid DNA Hybrids}

The most commonly used DNA vector is the genetically engineered naked bacterial plasmid. The versatility, simplicity, and ease of production make naked plasmid DNA a popular vector [68]. Several novel approaches have been designed to link plasmid DNA onto the microbubble surface by physical incorporation into the microbubble shell during MCA formulation or electrostatic adsorption to pre-formed MCA's.

Incorporating plasmid DNA's into the microbubble shell during their formulation was first performed by Tuepe et al. [69] by incorporating Lac-Z expressing plasmid DNA into the shells of protein-based microbubbles. Plasmid-bearing MCA's insonified while flowing through a dissected porcine 
coronary artery increased $\beta$-galactosidase activity nearly 5 -fold more than plasmid. A similar study by Frenkel et al. [65] characterized the plasmid-bearing MCA's in more detail, demonstrating high surface DNA-loading capacities and no degradation of plasmids during microbubble formulation. Both of these studies demonstrated efficient transfection efficiencies of plasmids in vitro and ex vivo studies and have led to the development of in vivo experiments utilizing plasmid-microbubble hybrid vectors.

Bekerdejian et al. [24] demonstrated that incorporation of plasmid DNA into the MCA shell can result in highly specific targeted organ deposition to the heart. Plasmid DNA encoding for the luciferase protein was incorporated into albumin microbubbles, as described by Frenkel et al. [65]. The plasmid-loaded microbubbles were systemically administered into rats while US was applied over the thorax. Analysis of luciferase expression in multiple organs demonstrated targeted delivery to the heart, with only one animal (out of 6) exhibiting off-target expression in the liver. Similar results were obtained using plasmid-loaded lipid-based microbubbles [24]. This important study was one of the first experiments demonstrating efficient organ targeted gene delivery using US and DNA-loaded MCA's.

Christiansen et al. [36] demonstrated a simple yet elegant approach to DNA loading by incorporated cationic lipids into the shell of lipid stabilized microbubbles. The negatively charged DNA phosphate backbone can interact with positive charges on the pre-formed microbubble shell, thus MCA-plasmid hybrid vectors can be generated by simple mixing. The plasmid-loaded MCA's transfected both hind-limb skeletal muscle and cardiac tissue following systemic injections, demonstrating their viability for in vivo applications. Haag et al.[38] used a similar microbubble formulation to transfect prostate tumors in vivo using tumor growth-suppressing antisense oligodeoxynucleotides (ODN's) to down-regulate androgen receptor (AR) expression. Systemically administered ODN's were delivered to tumors; however no AR knockdown was detected. The lack of AR knockdown may be due to low ODN uptake beyond the vascular tissue. In fact, the studies by Tuepe et al. [69], Christiansen et al. [36], and Haag et al. [38], all demonstrate that plasmid DNA or ODN deposition primarily occurs in blood vessels and luminal tissue.

\section{Microbubble /Synthetic Vector Hybrids}

Non-viral vectors, such as liposomes and polymers, play an important role in prolonging circulation times of DNA and facilitating intracellular delivery [17]. As with plasmid DNA's, MCA cavitation can synergistically be used with non-viral DNA vectors to enhance gene transfection in vivo. A few studies have shown that co-injections of MCA's and non-viral DNA vectors can improve ultrasound mediated gene transfection in vivo $[41,70,71]$, demonstrating the potential of MCA's towards facilitating non-viral gene therapy strategies.

More novel approaches have been developed to incorporate non-viral vectors with the microbubble shell in order to improve DNA loading capacity and in vivo gene transfection efficiency [1]. Lentacker et al. [64] and Borden et al. [72] both used polyelectrolyte layering of cationic polymers to increase plasmid DNA loading onto the surface of microbubbles. Vandenbroucke et al. [73] engineered a novel microbubble hybrid utilizing liposomes to increase the levels of siRNA loading onto lipid microbubbles and demonstrated improved siRNA knockdown in vitro. While these formulations have demonstrated higher loading capacities, better protection, and more efficient transfection of the DNA, only a few formulations have been tested in vivo.

In 2002, Seemann et al.[74] published a study designed to incorporate polyplexes into the microbubble shell. Polyplexes of plasmid DNA complexed to cationic polymers (Polylysine, protamin sulfate, or polyethylenimine) were incorporated into the shell of PLGA-based polymer microbubbles. In vivo gene transfection studies using polylysine-based polyplexes, showed efficient US targeting of B-galactosidase expressing plasmid DNA to tumor tissue [75]. Gene transfection experiments were performed with plasmid DNA encoding for the p16 tumor suppressor gene as well, which slowed late-stage tumor growth in adult mice.

Single polyelectrolyte layering of lipid MCA's have recently been used in vivo for targeting plasmid DNA to the liver. Wang et al. used polylysine coated lipid MCA's to deliver hepatocyte growth factor (HGR) expressing plasmids to treat liver fibrosis [76]. Systemic administration of plasmid-coated MCA's resulted in increased HGR expression and lower collagen I density compared to controls without US and without MCA's. A similar study by Zhou et al. has demonstrated effective tumor targeting of plasmids conjugated to polylysine-coated lipid MCA's [77]. A herpes simplex virus thymus kinase (HSV-TK) expressing plasmid DNA was loaded onto polylysine coated lipid MCA's and then delivered systemically into mice by tail vein administration. The cell suicide inducing HSV-TK plasmids showed a 2.2-fold increase in apoptotic effect in tumors treated when US was applied to plasmid-loaded MCA's compared to the plasmid alone. Tumor growth was significantly 
slowed using US and plasmid loaded-MCA's compared to controls as well.

Recently, our group has published a study outlining a strategy to covalently bind PEI-based plasmid vectors to the surface of lipid microbubbles [42]. PEI-coated microbubbles were mixed with luciferase expressing plasmid DNA to form PEI/DNA polyplex-MCA hybrids. The hybrids were delivered sys- temically into tumor bearing mice by tail vein injections while US was applied directly to the tumor tissue (Figure 8). Luciferase expression was detected only in the region of US irradiation 24 hours following MCA-mediated gene transfection. No luciferase expression was observed without US, indicating that MCA cavitation was the primary mechanism of plasmid delivery to tumor tissue.
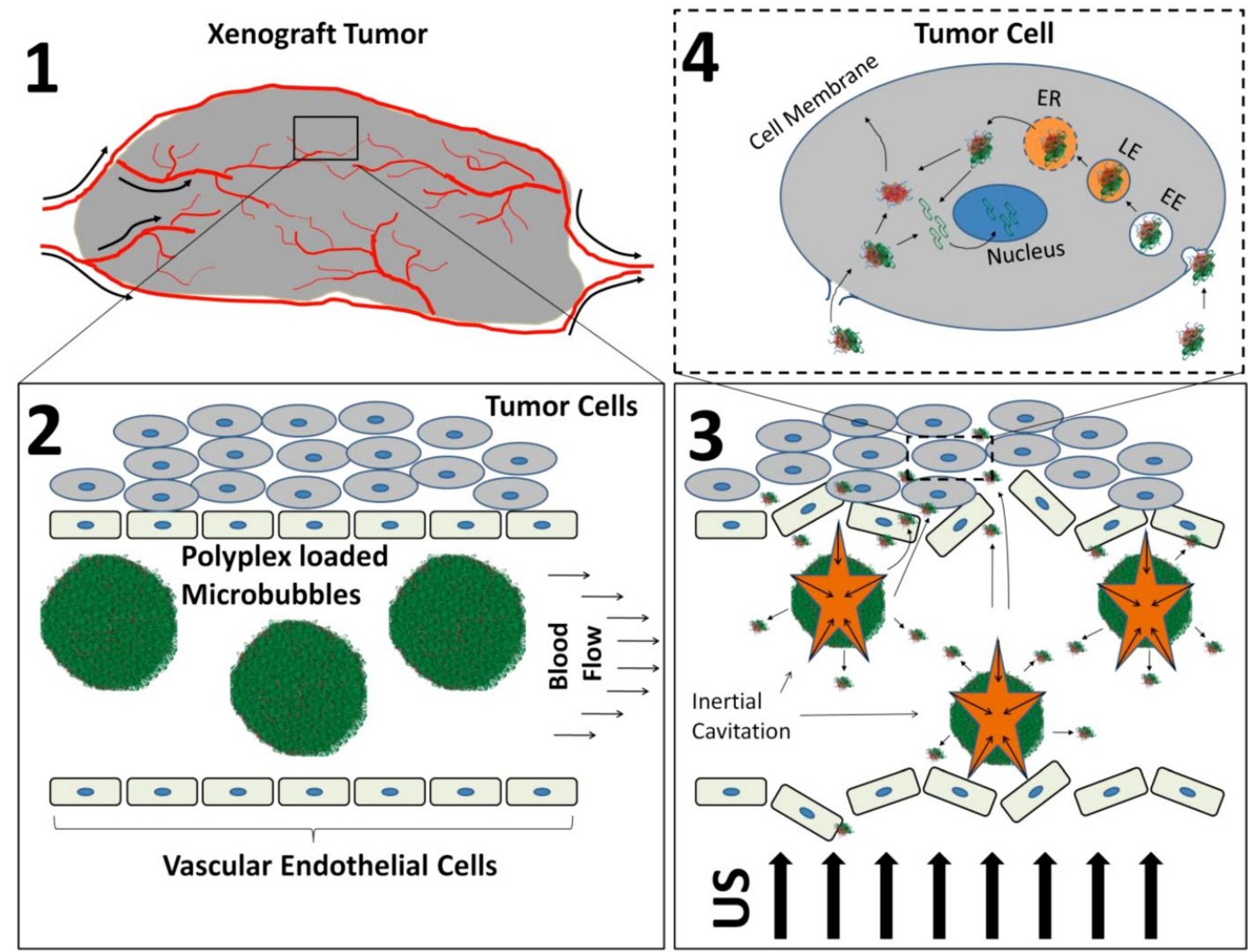

Figure 8. Schematic describing how polyplex-loaded MCA are used to delivery plasmid DNA to xenograft tumors. I) Xenograft tumors are implanted in nude mice and allowed to grow until they are approximately I gram in size. 2) Polyplex-loaded MCA's are introduced systemically via tail vein administration. 3) US is applied to induce MCA cavitation and polyplex release from the MCA shell. 4) Polyplexes are delivered to tumor tissue where they facilitate intracellular plasmid DNA uptake and delivery to the cell nucleus. Re-printed with permission from Sirsi et al. [3I].

\section{Microbubble/Virus hybrids}

Naked DNA uptake and non-viral vector systems exhibit notoriously low levels of gene expression. Viral vectors, on the other hand, are highly efficient transfection agents that do not require higher delivery payloads. One of the main drawbacks in systemic delivery of viral vectors is toxicity due to high hepatic deposition of viral particles, limiting dosages that can be delivered [19]. MCA's can be utilized in synergy with viral vectors to direct virus deposition to target tissue, improving payload of delivery and increasing the therapeutic index. Therefore,
MCA's can be a valuable tool for reducing toxicity associated with viral vector systems. Co-injections of viral vectors and MCA's have demonstrated improved gene transfection in vivo [78, 79]. However, in order to provide more controlled release of the viral particles, surface loading onto the microbubble shell is a more popular approach.

Several studies have utilized MCA-virus hybrid vectors to augment delivery of viral vectors to cardiac tissue. [26, 80-82]. Shohet et al. [26] demonstrated efficient targeting of $B$-galactose expressing adenoviral vectors to the myocardium by loading the viral particles onto the surface of albumin microbubbles. Ade- 
noviral-coated microbubbles were systemically administered into rats while the heart was exposed to US. B-galactose expression was only detected in the myocardium following US exposure with microbubbles, demonstrating the earliest proof-of-concept for organ specific targeting of adenoviral vectors.

Similar studies by Chen et al. and Müller et al, utilized surface loading of adeno-associated virus to target gene expression in the heart $[80,81]$. Chen et al. [80] compared the transfection efficiencies and biodistribution of luciferase expressing AAV and plasmids loaded onto lipid microbubbles. Cationic lipids were introduced into the microbubble shells that facilitate electrostatic binding of plasmids and adeno-associated viral (AAV) vectors. Luciferase expressing plasmid- and AAV-MCA's were introduced systemically while applying US to the heart. Results from AAV and plasmid transfection demonstrated efficient luciferase expression in cardiac tissue. However off-target expression in the liver was observed with AAV's, but not with plasmid vectors. This result may be attributed to the high tropism of AAV to the liver or more rapid degradation of the plasmid DNA's in hepatic tissue. Müller et al. [81] also demonstrated effective organ specific expression of luciferase encoding AAV-6 and AAV-9 serotype vectors in rat cardiac tissue following systemic administration of AAV loaded MCA's. Luciferase expression 4 weeks after transfection was detectable only in the heart and liver using the AAV-6 serotype, and only the heart for the AAV-9 serotype.

Table 2. Novel DNA loading strategies that have demonstrated in vivo gene transfection.

\begin{tabular}{|c|c|c|c|}
\hline Author & Year & Approach & Summary \\
\hline Shohet et al [26] & 2000 & $\begin{array}{l}\text { Adenoviral particles } \\
\text { loaded on the surface } \\
\text { of albumin-shell } \\
\text { microbubbles }\end{array}$ & $\begin{array}{l}\text { - Successfully demonstrated site-specific } \\
\text { gene expression in the myocardium using } \\
\text { US targeting }\end{array}$ \\
\hline $\begin{array}{l}\text { Seeman et al. [74] } \\
\text { and } \\
\text { Hauff et al. [75] }\end{array}$ & $\begin{array}{l}2002 \\
2005\end{array}$ & $\begin{array}{l}\text { Cationic polyplexes } \\
\text { incorporated within a } \\
\text { polymer microbubble } \\
\text { shell }\end{array}$ & $\begin{array}{l}\text { - Successfully delivered } \beta \text {-galactosidase } \\
\text { expressing plasmid DNA targeted to tumor } \\
\text { tissue } \\
\text {-Gene transfection with P16 expressing } \\
\text { plasmid DNA successfully slowed late-stage } \\
\text { tumor growth in adult mice }\end{array}$ \\
\hline $\begin{array}{l}\text { Chen et al. [80] } \\
\text { and } \\
\text { Muller et al. [81] }\end{array}$ & $\begin{array}{l}2003 \\
2008\end{array}$ & $\begin{array}{l}\text { Loaded different AAV } \\
\text { serotypes onto } \\
\text { cationic lipid-based } \\
\text { microbubbles }\end{array}$ & $\begin{array}{l}\text { - Successfully demonstrated organ- specific } \\
\text { gene expression in the heart using US } \\
\text { targeting } \\
\text { - Demonstrated sustained gene expression } 4 \\
\text { weeks after transfection }\end{array}$ \\
\hline Bekeredjian et al. [24] & 2003 & $\begin{array}{l}\text { Loaded Plasmid DNA } \\
\text { into albumin or lipid } \\
\text { microbubble shells } \\
\text { during fabrication }\end{array}$ & $\begin{array}{l}\text { - Successfully demonstrated organ- specific } \\
\text { gene expression in the heart using US } \\
\text { targeting }\end{array}$ \\
\hline $\begin{array}{l}\text { Christiansen et al. [36] } \\
\text { and } \\
\text { Haag et al. [38] }\end{array}$ & 2003 & $\begin{array}{l}\text { Loaded plasmids or } \\
\text { ODN's electrostically } \\
\text { onto pre-formed } \\
\text { cationic lipid-based } \\
\text { microbubbles }\end{array}$ & $\begin{array}{l}\text { - Successfully transfected both hind-limb } \\
\text { skeletal muscle and cardiac tissue following } \\
\text { intra-arterial or intravenous injections using } \\
\text { US targeting } \\
\text { - Successfully delivered ODN's to tumor } \\
\text { tissue although no functional effect was } \\
\text { observed }\end{array}$ \\
\hline $\begin{array}{l}\text { Wang et al. [76] } \\
\text { and } \\
\text { Zhou et al. [77] }\end{array}$ & 2011 & $\begin{array}{l}\text { Loaded plasmids } \\
\text { electrostatically onto } \\
\text { polylysine coated lipid- } \\
\text { based microbubbles }\end{array}$ & $\begin{array}{l}\text {-Successfully demonstrated increased HGR } \\
\text { expression and lowered Collagen I density in } \\
\text { hepatic tissue using HGR-expressing } \\
\text { plasmids } \\
\text { - Demonstrated increased apoptotic effect in } \\
\text { tumors and slower tumor growth using } \\
\text { HSV-TK }\end{array}$ \\
\hline Sirsi et al. [42] & 2012 & $\begin{array}{l}\text { Covalently attached } \\
\text { cationic polyplexes to } \\
\text { the surface of lipid } \\
\text { microbubbles }\end{array}$ & $\begin{array}{l}\text { - Successfully demonstrated site-specific } \\
\text { gene expression in xenograft tumors } \\
\text { following systemic delivery of Luciferase } \\
\text { expressing plasmids }\end{array}$ \\
\hline
\end{tabular}




\section{Future Prospects}

In this review, we have discussed the potential mechanisms of DNA delivery and novel strategies that have been developed to provide successful methods of target specific gene delivery. Although these novel strategies do show promise, further development in this field is still needed to demonstrate efficient gene delivery and functional therapeutic effects. Here we discuss some consideration that should be addressed in developing next-generation MCA's for gene delivery applications.

\section{Microbubble Surface Architecture}

The microbubble shell architecture and has composition have a profound impact on the response of the MCA in an ultrasound field as well as drug loading and kinetic release properties (for a comprehensive review on the effects of microbubble shell type in imaging and drug delivery applications, see [1]). Recently, Mehier-Humbert al. showed that the MCA shell material (polymer vs. lipid shell) and gas core composition significantly influenced transfection efficiencies in vivo [83]. Nomikou et al. [84] also demonstrated a modest increase in in vivo gene transfection efficiency following intramuscular injections of biotinylated MCA's.

Modulation of the MCA surface can consequently affect their circulation properties and bio-distribution in vivo as well, potentially reducing transfection efficiencies. We have recently shown that cationic MCA-polymer hybrids, comprised of modified polyethylenimine polymers loaded on the surface of lipid-based microbubbles, demonstrate markedly reduced circulation half-lives and high levels of non-specific binding to the vasculature [42]. When the cationic MCA's were coated with DNA and the surface charge was reversed, the circulation half-lives dramatically improved. Novel strategies have been proposed in order to hide surface moieties by burying them beneath a PEG overbrush [85-88]. Although these design strategies have only been tested with small peptides $(<1 \mathrm{kDa})$, similar strategies in principle could be employed to shield surface loaded DNA vectors.

\section{Microbubble Size}

Tailoring the MCA size can significantly increase the circulation life of the contrast agent $[89,90]$, thus improving the likelihood that the circulating microbubbles will be destroyed at the target site. Tailoring the MCA size can also influence the mechanisms vascular extravasation and DNA delivery to tissue. A recent in vivo study by [91] demonstrated transient opening of the blood brain barrier (BBB) using size-selected MCA's ranging from 1-8 $\mu \mathrm{m}$ in diameter. Targeted extravasation and deposition of circulating fluorescent dextrans in the hippocampus could be achieved by stable cavitation of larger size-selected lipid MCA's $(>4 \mu \mathrm{m})$ whereas smaller MCA $(1-2 \mu \mathrm{m})$ required higher pressures. The results of this study imply that BBB opening can be successfully achieved by volumetric oscillation of the larger MCA's rather than violent MCA collapse, which may be associated with deleterious bioeffects.

Table 3. Summary of future design considerations for next-generation MCA's.

\begin{tabular}{|c|c|}
\hline Design Consideration & Summary \\
\hline $\begin{array}{l}\text { Microbubble Surface Architecture } \\
\text { and Shell Composition }\end{array}$ & $\begin{array}{l}\text {-Affects response of MB's in an ultrasound field } \\
\text {-Affects Loading Capacity } \\
\text {-Affects Drug Release Kinetics } \\
\text {-Affects Circulation Life } \\
\text {-Affects Biodistribution }\end{array}$ \\
\hline Microbubble Size & $\begin{array}{l}\text { - Affects Circulation Life } \\
\text { - Affects cavitation threshold } \\
\text { - Affects volumetric expansion within the blood vessel }\end{array}$ \\
\hline Molecular Targeting & $\begin{array}{l}\text { - Affects microbubble-cell membrane association } \\
\text { - Increases target specificity }\end{array}$ \\
\hline $\begin{array}{l}\text { Ultrasound Application } \\
\text { (Peak Negative Pressure, Frequency, Pulse } \\
\text { repetition rate) }\end{array}$ & $\begin{array}{l}\text { - Affects method of cavitation (Stable vs. Inertial) } \\
\text { - Affects microbubble displacement in flow (radiation forces) }\end{array}$ \\
\hline
\end{tabular}




\section{Molecular targeting}

One of the most promising approaches to improving organ specific gene delivery is to apply molecular targeting strategies to the MCA delivery vectors $[5,20]$. Molecular targeting would allow MCA's to preferentially accumulate in areas of interest, improve the association of MCA's with the vascular endothelium, and enhance the effects of sonoporation. This strategy of utilizing molecular targeting to enhance sonoporation has been explored in vitro using CD31-targeting microbubbles [92], however no studies that we are aware of have demonstrated the efficacy of this strategy in vivo.

\section{Ultrasound Application}

The application of US and the parameters that govern the US field have a profound impact on the microbubble response and resulting bio-effects (for a detailed review, see Ferrara et al. [93] and Coussiois et al. [94]). The US peak negative pressure and frequency govern the mechanisms of cavitation, and therefore the resulting bio-effects. In addition to changing the method of cavitation, US pulse intervals should be considered to allow replenishment of fresh circulating bubbles throughout the insonified region [26]. More novel approaches utilizing US radiation forces can also be used to facilitate interaction of circulating MB's with the blood vessel walls, potentially increasing the bio-effects of cavitation $[55,93]$.

\section{Summary}

Overall, the progress in the field is demonstrating significant potential for developing more efficient and target-specific gene expression; however, almost all of the recent studies are focused on demonstrating proof-of-concept. More in-depth studies are required to prove the efficacy of next-generation MCA's and demonstrate they are clinically viable for improved target specificity as well as more efficient and prolonged gene expression.

\section{Competing Interests}

The authors have declared that no competing interest exists.

\section{References}

1. Sirsi S, Borden M. Microbubble Compositions, Properties and Biomedical Applications. Bubble Sci Eng Technol. 2009; 1: 3-17.

2. Chadderdon SM, Kaul S. Molecular imaging with contrast enhanced ultrasound. J Nucl Cardiol. 2010; 17: 667-77.

3. Inaba Y, Lindner JR. Molecular imaging of disease with targeted contrast ultrasound imaging. Transl Res. 2012; 159: 140-8.

4. Kiessling F, Bzyl J, Fokong S, Siepmann M, Schmitz G, Palmowski M. Targeted ultrasound imaging of cancer: an emerging technology on its way to clinics. Curr Pharm Des. 2012; 18: 2184-99.
5. Kiessling F, Fokong S, Koczera P, Lederle W, Lammers T. Ultrasound microbubbles for molecular diagnosis, therapy, and theranostics. J Nucl Med. 2012; 53: 345-8.

6. Kaufmann BA, Lindner JR. Molecular imaging with targeted contrast ultrasound. Curr Opin Biotechnol. 2007; 18: 11-6.

7. Lindner JR. Molecular imaging with contrast ultrasound and targeted microbubbles. J Nucl Cardiol. 2004; 11: 215-21.

8. Moestue SA, Gribbestad IS, Hansen R. Intravascular Targets for Molecular Contrast-Enhanced Ultrasound Imaging. International Journal of Molecular Sciences. 2012; 13: 6679-97.

9. Geis NA, Katus HA, Bekeredjian R. Microbubbles as a vehicle for gene and drug delivery: current clinical implications and future perspectives. Curr Pharm Des. 2012; 18: 2166-83.

10. Wei K. Future applications of contrast ultrasound. J Cardiovasc Ultrasound. 2010; 19: 107-14.

11. Qin S, Caskey CF, Ferrara KW. Ultrasound contrast microbubbles in imaging and therapy: physical principles and engineering. Phys Med Biol. 2009; 54: R27-57.

12. Yi Y, Noh MJ, Lee KH. Current advances in retroviral gene therapy. Curr Gene Ther. 2011; 11: 218-28.

13. Kappes JC, Wu X. Safety considerations in vector development. Somat Cell Mol Genet. 2001; 26: 147-58.

14. Nair V. Retrovirus-induced oncogenesis and safety of retroviral vectors. Curr Opin Mol Ther. 2008; 10: 431-8.

15. Yi Y, Hahm SH, Lee KH. Retroviral gene therapy: safety issues and possible solutions. Curr Gene Ther. 2005; 5: 25-35.

16. Patil SD, Rhodes DG, Burgess DJ. DNA-based therapeutics and DNA delivery systems: a comprehensive review. AAPS J. 2005; 7: E61-77.

17. Liu C, Zhang N. Nanoparticles in gene therapy principles, prospects, and challenges. Prog Mol Biol Transl Sci. 2011; 104: 509-62.

18. Nishikawa M, Huang L. Nonviral vectors in the new millennium: delivery barriers in gene transfer. Hum Gene Ther. 2001; 12: 861-70.

19. Manickan E, Smith JS, Tian J, Eggerman TL, Lozier JN, Muller J, et al. Rapid Kupffer cell death after intravenous injection of adenovirus vectors. Mol Ther. 2006; 13: 108-17.

20. Klibanov AL. Microbubble contrast agents: targeted ultrasound imaging and ultrasound-assisted drug-delivery applications. Invest Radiol. 2006; 41: 354-62.

21. Korpanty G, Chen S, Shohet RV, Ding J, Yang B, Frenkel PA, et al. Targeting of VEGF-mediated angiogenesis to rat myocardium using ultrasonic destruction of microbubbles. Gene Ther. 2005; 12: 1305-12.

22. Tsunoda S, Mazda O, Oda Y, Iida Y, Akabame S, Kishida T, et al. Sonoporation using microbubble BR14 promotes pDNA/siRNA transduction to murine heart. Biochem Biophys Res Commun. 2005; 336: 118-27.

23. Zhigang W, Zhiyu L, Haitao R, Hong R, Qunxia Z, Ailong H, et al. Ultrasound-mediated microbubble destruction enhances VEGF gene delivery to the infarcted myocardium in rats. Clin Imaging. 2004; 28: 395-8.

24. Bekeredjian R, Chen S, Frenkel PA, Grayburn PA, Shohet RV. Ultrasound-targeted microbubble destruction can repeatedly direct highly specific plasmid expression to the heart. Circulation. 2003; 108: 1022-6.

25. Bekeredjian R, Grayburn PA, Shohet RV. Use of ultrasound contrast agents for gene or drug delivery in cardiovascular medicine. J Am Coll Cardiol. 2005; 45: 329-35.

26. Shohet RV, Chen S, Zhou YT, Wang Z, Meidell RS, Unger RH, et al. Echocardiographic destruction of albumin microbubbles directs gene delivery to the myocardium. Circulation. 2000; 101: 2554-6.

27. Chen S, Ding JH, Bekeredjian R, Yang BZ, Shohet RV, Johnston SA, et al. Efficient gene delivery to pancreatic islets with ultrasonic microbubble destruction technology. Proc Natl Acad Sci U S A. 2006; 103: 8469-74.

28. Chen S, Shimoda M, Wang MY, Ding J, Noguchi H, Matsumoto S, et al. Regeneration of pancreatic islets in vivo by ultrasound-targeted gene therapy. Gene Ther. 2010; 17: 1411-20.

29. Lan HY, Mu W, Tomita N, Huang XR, Li JH, Zhu HJ, et al. Inhibition of renal fibrosis by gene transfer of inducible Smad7 using ultrasound-microbubble system in rat UUO model. J Am Soc Nephrol. 2003; 14: $1535-48$

30. Koike H, Tomita N, Azuma H, Taniyama Y, Yamasaki K, Kunugiza Y, et al. An efficient gene transfer method mediated by ultrasound and microbubbles into the kidney. J Gene Med. 2005; 7: 108-16.

31. Chen YC, Jiang LP, Liu NX, Wang ZH, Hong K, Zhang QP. P85, Optison microbubbles and ultrasound cooperate in mediating plasmid DNA transfection in mouse skeletal muscles in vivo. Ultrason Sonochem. 2011; 18: 513-9.

32. Kuliszewski MA, Kobulnik J, Lindner JR, Stewart DJ, Leong-Poi H. Vascular gene transfer of SDF-1 promotes endothelial progenitor cell engraftment and enhances angiogenesis in ischemic muscle. Mol Ther. 2011; 19: 895-902. 
33. Wang X, Liang HD, Dong B, Lu QL, Blomley MJ. Gene transfer with microbubble ultrasound and plasmid DNA into skeletal muscle of mice: comparison between commercially available microbubble contrast agents. Radiology. 2005; 237: 224-9.

34. Zhang Q, Wang Z, Ran H, Fu X, Li X, Zheng Y, et al. Enhanced gene delivery into skeletal muscles with ultrasound and microbubble techniques. Acad Radiol. 2006; 13: 363-7.

35. Liao ZK, Tsai KC, Wang HT, Tseng SH, Deng WP, Chen WS, et al. Sonoporation-mediated anti-angiogenic gene transfer into muscle effectively regresses distant orthotopic tumors. Cancer Gene Ther. 2011.

36. Christiansen JP, French BA, Klibanov AL, Kaul S, Lindner JR. Targeted tissue transfection with ultrasound destruction of plasmid-bearing cationic microbubbles. Ultrasound Med Biol. 2003; 29: 1759-67.

37. Leong-Poi H, Kuliszewski MA, Lekas M, Sibbald M, Teichert-Kuliszewska K, Klibanov AL, et al. Therapeutic arteriogenesis by ultrasound-mediated VEGF165 plasmid gene delivery to chronically ischemic skeletal muscle. Circ Res. 2007; 101: 295-303.

38. Haag P, Frauscher F, Gradl J, Seitz A, Schafer G, Lindner JR, et al. Microbubble-enhanced ultrasound to deliver an antisense oligodeoxynucleotide targeting the human androgen receptor into prostate tumours. J Steroid Biochem Mol Biol. 2006; 102: 103-13.

39. Nie F, Xu HX, Lu MD, Wang Y, Tang Q. Anti-angiogenic gene therapy for hepatocellular carcinoma mediated by microbubble-enhanced ultrasound exposure: an in vivo experimental study. J Drug Target. 2008; 16 : 389-95.

40. Wang JF, Wang JB, Chen H, Zhang CM, Liu L, Pan SH, et al. Ultrasound-mediated microbubble destruction enhances gene transfection in pancreatic cancer cells. Adv Ther. 2008; 25: 412-21.

41. Chen ZY, Liang K, Qiu RX. Targeted gene delivery in tumor xenografts by the combination of ultrasound-targeted microbubble destruction and polyethylenimine to inhibit survivin gene expression and induce apoptosis. J Exp Clin Cancer Res. 2011; 29: 152.

42. Sirsi SR, Hernandez SL, Zielinski L, Blomback H, Koubaa A, Synder M, et al. Polyplex-microbubble hybrids for ultrasound-guided plasmid DNA delivery to solid tumors. J Control Release. 2012; 157-224-34.

43. Liang HD, Tang J, Halliwell M. Sonoporation, drug delivery, and gene therapy. Proc Inst Mech Eng H. 2010; 224: 343-61.

44. van Wamel A, Kooiman K, Harteveld M, Emmer M, ten Cate FJ, Versluis $\mathrm{M}$, et al. Vibrating microbubbles poking individual cells: drug transfer into cells via sonoporation. J Control Release. 2006; 112: 149-55.

45. Schlicher RK, Radhakrishna H, Tolentino TP, Apkarian RP, Zarnitsyn V, Prausnitz MR. Mechanism of intracellular delivery by acoustic cavitation. Ultrasound Med Biol. 2006; 32: 915-24.

46. Deng CX, Sieling F, Pan H, Cui J. Ultrasound-induced cell membrane porosity. Ultrasound Med Biol. 2004; 30: 519-26.

47. Mehier-Humbert S, Bettinger T, Yan F, Guy RH. Plasma membrane poration induced by ultrasound exposure: implication for drug delivery. J Control Release. 2005; 104: 213-22.

48. Moosavi Nejad S, Hosseini SH, Akiyama H, Tachibana K. Optical observation of cell sonoporation with low intensity ultrasound. Biochem Biophys Res Commun. 2011; 413: 218-23.

49. Zhou Y, Kumon RE, Cui J, Deng CX. The size of sonoporation pores on the cell membrane. Ultrasound Med Biol. 2009; 35: 1756-60.

50. Tran TA, Roger S, Le Guennec JY, Tranquart F, Bouakaz A. Effect of ultrasound-activated microbubbles on the cell electrophysiological properties. Ultrasound Med Biol. 2007; 33: 158-63.

51. Hassan MA, Campbell P, Kondo T. The role of $\mathrm{Ca}(2+)$ in ultrasound-elicited bioeffects: progress, perspectives and prospects. Drug Discov Today. 2010; 15: 892-906.

52. Zhou Y, Yang K, Cui J, Ye JY, Deng CX. Controlled permeation of cell membrane by single bubble acoustic cavitation. J Control Release. 2011; 157: 103-11.

53. Caskey CF, Stieger SM, Qin S, Dayton PA, Ferrara KW. Direct observations of ultrasound microbubble contrast agent interaction with the microvessel wall. J Acoust Soc Am. 2007; 122: 1191-200.

54. Chen H, Kreider W, Brayman AA, Bailey MR, Matula TJ. Blood vessel deformations on microsecond time scales by ultrasonic cavitation. Phys Rev Lett. 2011; 106: 034301.

55. Dayton PA, Allen JS, Ferrara KW. The magnitude of radiation force on ultrasound contrast agents. J Acoust Soc Am. 2002; 112: 2183-92.

56. Hauser J, Ellisman M, Steinau HU, Stefan E, Dudda M, Hauser M. Ultrasound enhanced endocytotic activity of human fibroblasts. Ultrasound Med Biol. 2009; 35: 2084-92.

57. Meijering BD, Juffermans LJ, van Wamel A, Henning RH, Zuhorn IS, Emmer $\mathrm{M}$, et al. Ultrasound and microbubble-targeted delivery of macromolecules is regulated by induction of endocytosis and pore formation. Circ Res. 2009; 104: 679-87.
58. Lentacker I, Wang N, Vandenbroucke RE, Demeester J, De Smedt SC, Sanders NN. Ultrasound exposure of lipoplex loaded microbubbles facilitates direct cytoplasmic entry of the lipoplexes. Mol Pharm. 2009; 6: 457-67.

59. Geers B, Lentacker I, Alonso A, Sanders NN, Demeester J, Meairs S, et al. Elucidating the mechanisms behind sonoporation with adeno-associated virus-loaded microbubbles. Mol Pharm. 2011; 8: 2244-51.

60. Kimmel E. Cavitation bioeffects. Crit Rev Biomed Eng. 2006; 34: 105-61.

61. Caskey CF, Qin S, Dayton PA, Ferrara KW. Microbubble tunneling in gel phantoms. J Acoust Soc Am. 2009; 125: EL183-9.

62. Arvanitis CD, Bazan-Peregrino M, Rifai B, Seymour LW, Coussios CC. Cavitation-enhanced extravasation for drug delivery. Ultrasound Med Biol. 2011;37: 1838-52

63. Lum AF, Borden MA, Dayton PA, Kruse DE, Simon SI, Ferrara KW. Ultrasound radiation force enables targeted deposition of model drug carriers loaded on microbubbles. J Control Release. 2006; 111: 128-34.

64. Lentacker I, De Geest BG, Vandenbroucke RE, Peeters L, Demeester J, De Smedt SC, et al. Ultrasound-responsive polymer-coated microbubbles that bind and protect DNA. Langmuir. 2006; 22: 7273-8.

65. Frenkel PA, Chen S, Thai T, Shohet RV, Grayburn PA. DNA-loaded albumin microbubbles enhance ultrasound-mediated transfection in vitro. Ultrasound Med Biol. 2002; 28: 817-22.

66. Lentacker I, Geers B, Demeester J, De Smedt SC, Sanders NN. Design and evaluation of doxorubicin-containing microbubbles for ultrasound-triggered doxorubicin delivery: cytotoxicity and mechanisms involved. Mol Ther. 2010; 18: 101-8.

67. Bekeredjian R, Chen S, Grayburn PA, Shohet RV. Augmentation of cardiac protein delivery using ultrasound targeted microbubble destruction. Ultrasound Med Biol. 2005; 31: 687-91.

68. Shimamura M, Morishita R. Naked plasmid DNA for gene therapy. Curr Gene Ther. 2011; 11.

69. Teupe C, Richter S, Fisslthaler B, Randriamboavonjy V, Ihling C, Fleming I, et al. Vascular gene transfer of phosphomimetic endothelial nitric oxide synthase (S1177D) using ultrasound-enhanced destruction of plasmid-loaded microbubbles improves vasoreactivity. Circulation. 2002; 105: 1104-9.

70. Chen Z, Xie M, Wang X, Lv Q, Ding S. Efficient gene delivery to myocardium with ultrasound targeted microbubble destruction and polyethylenimine. J Huazhong Univ Sci Technolog Med Sci. 2008; 28: 613-7.

71. Xenariou S, Griesenbach U, Liang HD, Zhu J, Farley R, Somerton L, et al. Use of ultrasound to enhance nonviral lung gene transfer in vivo. Gene Ther. 2007; 14: 768-74.

72. Borden MA, Caskey CF, Little E, Gillies RJ, Ferrara KW. DNA and polylysine adsorption and multilayer construction onto cationic lipid-coated microbubbles. Langmuir. 2007; 23: 9401-8.

73. Vandenbroucke RE, Lentacker I, Demeester J, De Smedt SC, Sanders NN. Ultrasound assisted siRNA delivery using PEG-siPlex loaded microbubbles. J Control Release. 2008; 126: 265-73.

74. Seemann S, Hauff P, Schultze-Mosgau M, Lehmann C, Reszka R. Pharmaceutical evaluation of gas-filled microparticles as gene delivery system. Pharm Res. 2002; 19: 250-7.

75. Hauff P, Seemann S, Reszka R, Schultze-Mosgau M, Reinhardt M, Buzasi $\mathrm{T}$, et al. Evaluation of gas-filled microparticles and sonoporation as gene delivery system: feasibility study in rodent tumor models. Radiology. 2005; 236: 572-8.

76. Wang ZX, Wang ZG, Ran HT, Ren JL, Zhang Y, Li Q, et al. The treatment of liver fibrosis induced by hepatocyte growth factor-directed, ultrasound-targeted microbubble destruction in rats. Clin Imaging. 2009; 33: 454-61.

77. Zhou S, Li S, Liu Z, Tang Y, Wang Z, Gong J, et al. Ultrasound-targeted microbubble destruction mediated herpes simplex virus-thymidine kinase gene treats hepatoma in mice. J Exp Clin Cancer Res. 2011; 29: 170.

78. Li HL, Zheng XZ, Wang HP, Li F, Wu Y, Du LF. Ultrasound-targeted microbubble destruction enhances AAV-mediated gene transfection in human RPE cells in vitro and rat retina in vivo. Gene Ther. 2009; 16: 1146-53.

79. Xie W, Liu S, Su H, Wang Z, Zheng Y, Fu Y. Ultrasound microbubbles enhance recombinant adeno-associated virus vector delivery to retinal ganglion cells in vivo. Acad Radiol. 2010; 17: 1242-8.

80. Chen S, Shohet RV, Bekeredjian R, Frenkel P, Grayburn PA. Optimization of ultrasound parameters for cardiac gene delivery of adenoviral or plasmid deoxyribonucleic acid by ultrasound-targeted microbubble destruction. J Am Coll Cardiol. 2003; 42: 301-8.

81. Muller OJ, Schinkel S, Kleinschmidt JA, Katus HA, Bekeredjian R. Augmentation of AAV-mediated cardiac gene transfer after systemic administration in adult rats. Gene Ther. 2008; 15: 1558-65. 
82. Bish LT, Sweeney HL, Muller OJ, Bekeredjian R. Adeno-associated virus vector delivery to the heart. Methods Mol Biol. 2011; 807: 219-37.

83. Mehier-Humbert S, Yan F, Frinking P, Schneider M, Guy RH, Bettinger $\mathrm{T}$. Ultrasound-mediated gene delivery: influence of contrast agent on transfection. Bioconjug Chem. 2007; 18: 652-62.

84. Nomikou N, Tiwari P, Trehan T, Gulati K, McHale AP. Studies on neutral, cationic and biotinylated cationic microbubbles in enhancing ultrasound-mediated gene delivery in vitro and in vivo. Acta Biomater. 2011.

85. Borden MA, Sarantos MR, Stieger SM, Simon SI, Ferrara KW, Dayton PA. Ultrasound radiation force modulates ligand availability on targeted contrast agents. Mol Imaging. 2006; 5: 139-47.

86. Borden MA, Zhang H, Gillies RJ, Dayton PA, Ferrara KW. A stimulus-responsive contrast agent for ultrasound molecular imaging. Biomaterials. 2008; 29: 597-606.

87. Chen CC, Borden MA. The role of poly(ethylene glycol) brush architecture in complement activation on targeted microbubble surfaces. Biomaterials. 2011; 32: 6579-87.

88. Chen CC, Sirsi SR, Homma S, Borden MA. Effect of surface architecture on in vivo ultrasound contrast persistence of targeted size-selected microbubbles. Ultrasound Med Biol. 2012; 38: 492-503.

89. Sirsi S, Feshitan J, Kwan J, Homma S, Borden M. Effect of microbubble size on fundamental mode high frequency ultrasound imaging in mice. Ultrasound Med Biol. 2010; 36: 935-48.

90. Streeter JE, Gessner R, Miles I, Dayton PA. Improving sensitivity in ultrasound molecular imaging by tailoring contrast agent size distribution: in vivo studies. Mol Imaging. 2010; 9: 87-95.

91. Tung YS, Vlachos F, Feshitan JA, Borden MA, Konofagou EE. The mechanism of interaction between focused ultrasound and microbubbles in blood-brain barrier opening in mice. J Acoust Soc Am. 2011; 130: 3059-67.

92. Kooiman K, Foppen-Harteveld M, van der Steen AF, de Jong N. Sonoporation of endothelial cells by vibrating targeted microbubbles. J Control Release. 2011; 154: 35-41.

93. Ferrara K, Pollard R, Borden M. Ultrasound microbubble contrast agents: fundamentals and application to gene and drug delivery. Annu Rev Biomed Eng. 2007; 9: 415-47.

94. Coussios CC, Roy RA. Applications of Acoustics and Cavitation to Noninvasive Therapy and Drug Delivery. Annual Review of Fluid Mechanics. 2008; 40: 395-420.

95. Krasovitski B, Frenkel V, Shoham S, Kimmel E. Intramembrane cavitation as a unifying mechanism for ultrasound-induced bioeffects. Proc Natl Acad Sci USA. 2011; 108: 3258-63.

96. Israelachvili JN. Intermolecular and Surface Forces. New York: Academic Press; 2011. 